DOI https://doi.org/10.18551/rjoas.2017-09.23

\title{
PROFILE OF PLASTIC WATER BOTTLES WASTES PROCESSING BUSINESS UNIT FOR WASTE PICKERS
}

\author{
Herijanto Pudji*, Fiernaningsih Nilawati \\ Department of Business Administration, Politeknik Negeri Malang, Indonesia \\ Widjanarko \\ Department of Mechanical Engineering, Politeknik Negeri Malang, Indonesia
}

*E-mail: pakherijanto@gmail.com

\begin{abstract}
Used plastic water bottles waste pickers can be categorized as one of the informal sector's component. They work for themselves by picking up used water bottles and selling them to the waste collectors. The problem to be solved in this research is How the Most Appropriate Used Plastic Water Bottles Business Model for Waste Pickers Is that enables them to be categorized as formal sector. From the result of the interview with 120 waste pickers, 96 results were qualified to be analyzed. The interview was located in several waste collectors, which were visited by waste pickers at certain hours. The data were analyzed descriptively based on six business aspects. Specifically for production facilities, Quality Function Deployment (QFD) and Value Engineering (VE) analysis were performed. The results of the analysis indicate that the business is practicable for waste pickers and has the potential to enable them run a formal business sector.
\end{abstract}

\section{KEY WORDS}

Informal sector, plastic waste, processing, business.

Waste pickers can be categorized as one of the informal sector's component. Siregar (2013) defines informal sector as a small-scale business unit which produces and distributes goods and services with creating job opportunities and income for themselves as the main purposes and physical capital and human resources as the main obstacles. A used plastic water bottles waste picker is definitely one of them. They work for themselves in picking up wastes, and then sell the wastes to waste collectors to get income.

Used plastic water bottles waste pickers also have the weaknesses commonly found in informal sector. The weaknesses include society judgment towards informal sector as a burden that pollutes the beauty and cleanliness of the city, failing to compete in both domestic and export markets, and lacks of product diversification (Hermawani, 2013).

Plastic water bottles waste processing is now widely operated since processed products have a high economic value. By being processed into plastic shreds, the price of the wastes can be at least doubled. Indeed, various supporting aspects are extremely needed to run this business. According to Prabowo (2012) and Kristiyono (2014), there are 6 aspects determining the feasibility of the establishment and/or development of plastic chopper factories, i.e. market, technical, legal and environmental, human resource management, and financial aspects. Although both of the researchers conducted the study at industrial level, the result of their findings could be applied to the informal sector such as waste pickers by considering their conditions.

The problem to be solved in this research is: How the Most Appropriate Used Plastic Water Bottles Business Model for Waste Pickers Is that enables them to be categorized as formal business sector. Thus, the aim of the research based on the problem is to describe the most appropriate used plastic water bottles business profile for waste pickers. 


\section{LITERATURE REVIEW}

Informal Sector. Informal sector is defined as a small-scale business unit which produces and distributes goods and services with the ultimate goal of creating job opportunities and income for themselves and the main constraints are physical capital and human resources (Siregar, 2013).

Some of the advantages of informal sector are: (a) Labor-intensive, generally informal sector is a labor-intensive small business; (b) Durability, the crisis proves that informal sector does not only survive, but also grow rapidly; (c) Special (Traditional) Expertise, the products they make are generally simple and need no formal education, but require special skills (traditional skill); (d) Capital, most entrepreneurs in informal sector depend on their own money (savings), or loan funds from informal sources (outside the banking / financial sector) for their capital needs.

Business Feasibility. Referring to the findings of Prabowo's (2012) and Kristiyono's (2014) studies, there are six aspects determining the feasibility of establishment and/or business development, i.e. market, technical, legal, environmental, human resources and financial aspects.

Market aspects assess existing market opportunities to run a potential business. It is done by comparing the amount of supply and demand. If demand is still higher and the quantity is quite economical, it means the market opportunity still exists.

Technical aspects relate to things that technically support the business. These aspects include at least land ownership, factory arrangement, technological mastery, and production process mastery. These points will ensure the production process run effectively and efficiently.

Legal aspects pertain to the legality of business actors and business units. Business actor must be a legal citizen with a legal residence. A business unit must have a license from the relevant department to be included as a formal business unit.

Environmental aspects concern the impact of a business towards the economic and social conditions of business actors and their environment. A good business certainly not only gives a positive impact on the business actors, but also has a positive impact on the environment.

Human resource management aspects deal with business actors' management. Business actors need to have minimum requirements for running a business, while their management is minimally accommodated in an organization with clear task structure and responsibilities.

The financial aspect measures the financial performance of a business. Sucipto, Oktaviani, and Rizal (2015) calculate financial performance with two measures, i.e. Return on Assets (ROA) and Return on Sales (ROS). ROA is ratio between net profits earned by total assets owned by the company while ROS is ratio of total profit earned by the company. ROA is a form of profitability ratio to measure a company's ability to generate profits by using the total existing assets and after the capital costs (the costs used to fund the assets) are excluded from the analysis (Margaretha, 2011). ROS measures how effectively sales made to provide income.

Quality Function Deployment (QFD). QFD is an analytical tool to describe customer needs, evaluate products or services systematically about its ability to meet those needs. The analysis is done by knowing the attributes the customer requires, customer satisfaction levels and comparison with customer satisfaction levels to other products (Adriantantri, 2008). Furthermore, Rahman \& Supomo (2012) state that QFD is usually used as a planning tool to meet the expectations and the needs of consumers, in which QFD is utilized to interpret the specific needs of the customer into engineering directions and measures.

Value Engineering. Pontoh (2013) concludes that value engineering intends to provide an optimal amount of the money spent by using systematic techniques to analyze and control the total product costs. Value Engineering will help distinguish and separate between necessity and alternative, so an option which meets the needs (and leaves the unnecessary) can be developed at the lowest cost. 


\section{METHODS OF RESEARCH}

This research is an explorative descriptive research that aims to describe the model of water bottles wastes chopping business for waste pickers. Data was collected through structured interviews with 120 waste pickers. Once verified, there were only 96 interviews that were qualified for analysis. The analysis was done descriptively to describe the business model as mentioned above.

\section{RESULTS OF STUDY}

Table 1, 2, and 3 illustrate the overview of the respondents based on age, gender, and interest in entrepreneurship.

Table 1 - Overview of Respondents by Age

\begin{tabular}{|c|c|c|c|}
\hline No. & Age & Total & $\%$ \\
\hline 1 & $15-20$ & 12 & $13 \%$ \\
\hline 2 & $21-26$ & 12 & $13 \%$ \\
\hline 3 & $27-32$ & 18 & $19 \%$ \\
\hline 4 & $33-38$ & 27 & $28 \%$ \\
\hline 5 & $39-44$ & 21 & $22 \%$ \\
\hline 6 & $45-50$ & 6 & $6 \%$ \\
\hline- & Total & 96 & $100 \%$ \\
\hline
\end{tabular}

Table 2 - Overview of Respondents by Gender

\begin{tabular}{|c|c|c|c|}
\hline No. & Gender & Total & $\%$ \\
\hline 1 & Female & 8 & 9 \\
\hline 2 & Male & 88 & 91 \\
\hline- & Total & 96 & 100 \\
\hline
\end{tabular}

Interest in Entrepreneurship. Several reasons of the respondents who are interested in this business include:

a. Providing working capital, i.e. as assets or business to create a better job.

b. Having known the business before.

c. Increasing income, that is processed plastic water bottles wastes have higher selling price than unprocessed bottles. Thus, it will be able to supplement their income.

Whereas the non-interested respondent has several reasons, i.e.:

a. Having no land. This is the most dominant reason of $38 \%$ of non-interested respondents.

b. Having inadequate knowledge about chopper tools or machines

c. Difficulty in finding the materials

d. Having no funds.

Table 3 - Interest in Entrepreneurship of Plastic Wastes Processing

\begin{tabular}{|c|c|c|c|}
\hline No. & Interest & Total & $\%$ \\
\hline 1 & Interested & 58 & 61 \\
\hline 2 & Not interested & 34 & 35 \\
\hline 3 & Abstain & 4 & 4 \\
\hline & Total & 96 & 100 \\
\hline
\end{tabular}

Source: Questionnaire (being processed).

Of 20 waste collectors state that the accommodated number of wastes is unlimited. Any amounts dropped by waste pickers will be accepted. On the other hand, waste pickers find it difficult to deposit in larger quantities due to the technical deliveries to the collectors. Waste pickers only place the bottles in the sack. Thus, despite the large volume of the sacks, they weigh very little. The survey results find that waste pickers averagely deposit 2.5 sacks per day, weighing about $1 \mathrm{~kg} / \mathrm{sack}$. 
Table 4 - Land Ownership

\begin{tabular}{|c|c|c|}
\hline Ownership & $\mathrm{n}$ & $\%$ \\
\hline Own & 42 & $44 \%$ \\
\hline Rent & 6 & $6 \%$ \\
\hline No ownership & 48 & $50 \%$ \\
\hline Total & 96 & $100 \%$ \\
\hline
\end{tabular}

In relation to the size of land owned, the majority of waste pickers have only a narrow remaining land, or even no more land left, which cause them to keep the wastes in the house temporarily. Furthermore, the landless waste pickers can be grouped into two, i.e. which still live together with parents or live with the relatives or friends.

Table 5 - Ownership of Motorcycles

\begin{tabular}{|c|c|c|}
\hline- & n & $\%$ \\
\hline Own & 72 & 75 \\
\hline No motor & 24 & 25 \\
\hline Total & 96 & 100 \\
\hline
\end{tabular}

Table 6 - Motorcycle Type

\begin{tabular}{|c|c|c|}
\hline- & $\mathrm{n}$ & $\%$ \\
\hline Automatic & 30 & 42 \\
\hline Regular & 42 & 58 \\
\hline Total & 72 & 100 \\
\hline
\end{tabular}

Table 7 - Machine Maintenance Capability

\begin{tabular}{|c|c|c|}
\hline- & $\mathrm{n}$ & 0 \\
\hline Major Damage & 0 & 0 \\
\hline Minor Damage & 63 & 98 \\
\hline Unable & 12 & 9 \\
\hline
\end{tabular}

Table 8 - Mastery of the Production Process

\begin{tabular}{|c|c|c|}
\hline- & $\mathrm{n}$ & $\%$ \\
\hline Have no understanding & 45 & 54 \\
\hline Have understanding & 24 & 28 \\
\hline Be able to & 15 & 18 \\
\hline Total & 84 & 100 \\
\hline
\end{tabular}

Referring to the input of waste pickers, the desired specifications of processed products are approximately $2 \mathrm{~mm}$ chopped outcome and more preferably in a clean condition.

The expected machine specification is a relatively small-sized machine which does not occupy many spaces, because the majority of them have no adequate land size to set up a factory. The machine should be portable enough to be carried by motorcycles because almost all waste pickers have one. The compact machine also eases the waste pickers in chopping the plastic bottles, instead of carrying them in large volumes.

Table 9 - Daily Income

\begin{tabular}{|c|c|c|}
\hline No & Income Level (in thousands) & $\mathrm{n}$ \\
\hline 1 & $25-35,5$ & 34 \\
\hline 2 & $>35,5-46$ & 14 \\
\hline 3 & $>46-56,5$ & 15 \\
\hline 4 & $>56,5-67$ & 22 \\
\hline 5 & $>67-77,5$ & 9 \\
\hline 6 & $>77,5-88$ & 2 \\
\hline \multicolumn{2}{|c|}{ Total } & 96 \\
\hline
\end{tabular}


The above incomes data is the total revenue from waste picking result. The results obtained from selling plastic water bottles wastes can be determined from the deposited bottles from waste pickers to waste collectors. As discussed in the business aspect, waste pickers averagely deposit 2.5 sacks, which is equivalent to $2.5 \mathrm{~kg}$. Price per $\mathrm{kg}$ is $\mathrm{Rp} 7,500,-$, so their income is Rp 18,750, -.

The earned income will be different if waste pickers initially sort the water bottles wastes because the prices of each part are different. A bottle is usually divided into four parts, i.e. the cap, the bottle neck, the body and the bottom of the bottle. The bottle cap costs Rp 3000, - / kg, the body is Rp 8.500, - / kg, and the neck and bottom can reach $R p$ 9,500, -. Similarly, for glasses wastes, it should be separated between the upper (thicker) circular parts with the body and bottom parts. Table 10.

Once being sorted, the price of $1 \mathrm{~kg}$ of bottles wastes can be calculated as seen from

Table 10 - Price After Sorting Process

\begin{tabular}{|c|c|c|c|c|c|}
\hline No & Part & $\%$ & $\mathrm{Kg}$ & $\mathrm{Rp} /$ piece & Rp sold \\
\hline 1 & Cap & 10 & 0,10 & 3000 & 300 \\
\hline 2 & Neck and Bottom & 15 & 0,15 & 9.500 & 950 \\
\hline 3 & 75 & 0,75 & 8.500 & 6.375 \\
\hline \multicolumn{3}{|c|}{ Price/Kg } & 8.100 \\
\hline \multicolumn{3}{|c|}{ Price without sorting process } & 7.500 \\
\hline
\end{tabular}

The results of waste picking enable $57 \%$ of waste pickers to have savings, as presented in Table 11.

Table 11 - Daily Savings

\begin{tabular}{|c|c|c|c|}
\hline No & Savings (in thousands) & $\mathrm{n}$ & $\%$ \\
\hline 1 & 0 & 41 & 43 \\
\hline 2 & 5 & 6 & 6 \\
\hline 3 & 10 & 14 & 15 \\
\hline 4 & 15 & 16 & 17 \\
\hline 5 & 20 & 11 & 11 \\
\hline 6 & 25 & 6 & 6 \\
\hline 7 & 30 & 2 & 2 \\
\hline \multicolumn{2}{r|}{} & 96 & 100 \\
\hline
\end{tabular}

Daily work pattern of $72 \%$ waste pickers is to work on their own, while the remaining $28 \%$ work in groups of 3 to 7 people. Their group is an informal group based on friendship and family relationships, causing them to have no formal organizational structure. Distance of the residential location between members is in one house or different houses in one urban village.

Table 12 - Waste Pickers' Educational Level

\begin{tabular}{|c|c|c|}
\hline Educational Level & $\mathrm{n}$ & $\%$ \\
\hline Elementary & 43 & 45 \\
\hline Junior High School & 44 & 46 \\
\hline Senior High School & 9 & 9 \\
\hline Total & 96 & 100 \\
\hline
\end{tabular}

The work ethic of waste pickers is generally very high to meet personal and / or family needs. In general, family dependents include daily needs fulfillment for children, wife / husband, and parents and the educational needs of their children. This is in line with their high work ethics which aims to improve the welfare by increasing income and working more easily.

Some waste pickers with ID cards do not have a permanent residence because they are non-native Malang or they still stay with parents or relatives. 
Table 13 - Family Dependents

\begin{tabular}{|c|c|c|}
\hline Dependent (person) & $n$ & $\%$ \\
\hline 0 & 13 & 14 \\
\hline 1 & 8 & 8 \\
\hline 2 & 32 & 33 \\
\hline 3 & 18 & 19 \\
\hline 4 & 12 & 13 \\
\hline 5 & 9 & 9 \\
\hline 6 & 4 & 4 \\
\hline Total & 96 & 100 \\
\hline
\end{tabular}

Table 14 - Ownership of ID card

\begin{tabular}{|c|c|c|}
\hline- & $\mathrm{n}$ & $\%$ \\
\hline Own & 90 & 94 \\
\hline No & 6 & 6 \\
\hline Total & 96 & 100 \\
\hline
\end{tabular}

Table 15 - Residence

\begin{tabular}{|c|c|c|}
\hline- & $n$ & $\%$ \\
\hline Permanent & 81 & 84 \\
\hline Non-Permanent & 15 & 16 \\
\hline Total & 96 & 100 \\
\hline
\end{tabular}

Table 16 - Socio-Economic Aspects

\begin{tabular}{|c|c|c|c|}
\hline Socio-Economic Aspects & Yes & No & Abstain \\
\hline Increase family economy & $91 \%$ & - & $9 \%$ \\
\hline Improve social status & $81 \%$ & - & $19 \%$ \\
\hline Reduce social problems & $75 \%$ & $6 \%$ & $13 \%$ \\
\hline
\end{tabular}

All respondents have no business documents because they are still informal economy actors.

\section{DISCUSSION OF RESULTS}

Market Aspects. From the results of the research, it can be concluded that waste collectors offer limitless demands, while the ability of waste pickers to meet the demand is still limited. By comparing the demand of unlimited number of wastes by waste collectors and supply from waste pickers, the market opportunity is still widely open.

Technical Aspects. In terms of land ownership, most waste pickers do not have enough area to run the business. From the data of motorcycle ownership, almost all waste pickers have motorcycles. Considering that the size of the plastic chopper machine is only $70 \mathrm{~cm} \mathrm{x}$ $45 \mathrm{~cm}$, this unit is transportable on a motorcycle. Thus, it enables the landless waste pickers to run plastic wastes chopper business, even without land ownership.

From the ability to repair motorcycle engine damage, $88 \%$ waste pickers are able to repair minor damage. Since the chopper machine working system is almost the same as a motorcycle engine, waste pickers will be able to minimally perform maintenance of the machine.

From the understanding of production process, $54 \%$ of waste pickers do not understand the process. Thus, to be able to run the plastic wastes chopping business, waste pickers need to be trained. It can be taken with a group effort, where there is at least one person familiar with the production process in each group.

Referring to the results of interviews with one of the waste collectors who have a chopper machine, the production process of plastic chopping is quite simple. For bottles, the process includes: 1) Separate the cap, neck, body parts, and the bottom of the bottle. 2) Separate the lid and put the body, neck and bottom together. 3) Chop the parts separately according to the group. Then for glasses, firstly the upper circle of the glass and body are 
separated. In chopping process, the top circle of glasses can be mixed with the neck and bottom parts of the bottles, then the glasses' body parts are put together with the body parts of the bottles.

The results are sold separately because each product has different price. The price figure is presented in table 10 .

From the description of technical aspects, the required facilities to run this business are motorcycle, chopper machine, and maintenance equipment for minor service. Accordingly, the value of the assets required to conduct the business is as follows:

Table 17 - Asset Value Calculation

\begin{tabular}{|c|c|c|c|c|c|}
\hline No & Description & $Q$ & Unit & $\begin{array}{c}\text { @Rp } \\
(000)\end{array}$ & $\begin{array}{c}\text { Rp Total } \\
(000)\end{array}$ \\
\hline 1 & Motorcycle & 0,4 & piece & 15.000 & 6.000 \\
\hline 2 & Machine & 1 & piece & 5.000 & 5.000 \\
\hline 3 & Tolls kit & 1 & set & 100 & 100 \\
\hline \multicolumn{7}{|c|}{ Total Asset Value } \\
\hline
\end{tabular}

Financial Aspects. Daily income from collecting plastic water bottles wastes after being sorted is Rp 8.100, -. The price will be doubled for chopped bottles. Then, the daily income will be as follows:

Table 18 - Monthly Income After Being Chopped

\begin{tabular}{|c|c|c|c|c|c|}
\hline No & Part & $\mathrm{Kg}$ & Rp/ Part & * & Rp Sold \\
\hline 1 & Cap & 0,10 & 3000 & 2 & 1.200 \\
\hline 2 & Neck and Bottom & 0,15 & 9.500 & 2 & 1.800 \\
\hline 3 & Body & 0,75 & 8.500 & 2 & 12.750 \\
\hline \multicolumn{5}{|c|}{ Price $/ \mathrm{Kg}$} & 15.750 \\
\hline \multicolumn{5}{|c|}{ Income / day with $2.5 \mathrm{~kg}$ results } & 39.375 \\
\hline \multicolumn{5}{|c|}{ Results Per month with 6 working days } & 945.000 \\
\hline \multicolumn{5}{|c|}{ Annual Gross Income } & 11.340 .000 \\
\hline
\end{tabular}

Source: Table 10 (processed, 2017).

To obtain the above results, the monthly operating costs are:

Table 19 - Monthly Operating Costs

\begin{tabular}{|c|c|c|c|c|c|}
\hline No & Description & Q & Unit & @Rp & Total Rp \\
\hline 1 & Raw material & 2,5 & $\mathrm{~kg}$ & 0 & 0 \\
\hline 2 & Labor & 1 & orang & 5000 & 5.000 \\
\hline 3 & Partiality & 1,5 & liter & 7500 & 10.850 \\
\hline \multicolumn{4}{|r|}{ Daily Operating Costs } \\
\hline
\end{tabular}

Therefore, the calculation of annual operating costs is:

Table 20 - Monthly Operating Costs

\begin{tabular}{|c|c|c|c|c|c|}
\hline No & Description & Q & Unit & $@ R p$ & Total Rp \\
\hline 1 & Monthly Operating Cost & 12 & month & 380.400 & 4.564 .800 \\
\hline 2 & Annual Depreciation & 1 & year & 1.000 .000 & 1.000 .000 \\
\hline 3 & Machine Maintenance & 1,5 & year & 500.000 & 500.000 \\
\hline \multicolumn{2}{|r|}{ Total Annual Operating Cost } & 6.064 .800 \\
\hline
\end{tabular}

From Table 18 and Table 20, the net income / year is Rp 11,340,000 - Rp 6,064,800 = Rp 5,275,200, -.

Referring to the previous data, the analysis of financial performance of this business is: 


\begin{tabular}{|c|c|c|c|c|}
\hline \multirow[b]{2}{*}{$\mathrm{ROA}=$} & $5,275,200$ & \multirow[b]{2}{*}{$x$} & \multirow[b]{2}{*}{$100 \%=$} & \multirow[b]{2}{*}{$47.96 \%$} \\
\hline & 11,000,000 & & & \\
\hline \multirow[b]{2}{*}{$\mathrm{ROS}=$} & $5,275,200$ & \multirow[b]{2}{*}{$x$} & \multirow[b]{2}{*}{$100 \%=$} & \multirow[b]{2}{*}{$46.52 \%$} \\
\hline & 11.340 .000 & & & \\
\hline
\end{tabular}

From the calculation of ROA and ROS, it can be seen that the capitals invested in this business can generate profits of $47.96 \%$ of the investment. Besides, it means that the business profit is $46.52 \%$ of total sales value. Thus, based on the value of ROA and ROS, this business can be financially categorized well.

Aspects of Organization and Human Resources. The daily work patterns of the waste pickers are $72 \%$ waste pickers working on their own, while the remaining $28 \%$ working in groups of 3 to 7 people. They have family relationships and friendships. They inhabit in one area of the urban village. From the conditions mentioned above, the most appropriate organization for them is individual organizations and individual alliances.

Educational level of waste pickers ranges from elementary to high school. Referring to the Indonesian National Qualification Framework, the qualification of primary and secondary graduates are operators, causing them to have no managerial ability. Consequently, establishment of a formal organization is not yet possible. Siagian (1996: 63) argues that "Managerial skills are the skill of moving others to work well." Referring to the above opinion, there will be "elder figures" in every social group, who will usually be the role models of the group. This will certainly appear also in the waste pickers group. Thus, even though their formal educations reach a maximum of high school, it is possible for them to establish formal organizations.

The work ethic of waste pickers is very high to meet personal and / or family needs. They have similar work ethics. It is also one of the supporting factors in establishing an organization which is having the same purpose.

Legal Aspects. Of ownership of ID card, $96 \%$ of waste pickers have ID card. In addition, they also have a permanent residence. This is a general requirement to conduct formal activities, including opening a formal business and conducting business-related activities such as credit application to the bank.

Socio-Economic Aspects. The number of respondents who agree that this business will increase the family economy is $91 \%$. The family economy will be improved due to the increasing income from selling chopped plastic wastes. Moreover, they also have a business capital in the form of chopper machine which facilitates their work processes.

Furthermore, $81 \%$ respondents believe that running a plastic bottles chopping business will improve their status. They can be self-supporting and not depend anymore on the waste collectors. In addition, they can even be the waste collectors for their friends who do not have a machine yet.

Finally, $75 \%$ waste pickers argue that having a chopping business will reduce social problems. Some argue that they will be able to provide jobs for their unemployed friends. In addition, they also feel involved in maintaining the cleanliness of the environment by processing plastic wastes into plastic pieces.

\section{CONCLUSION}

From the results of the discussion, it can be concluded that Plastic Water Bottles Wastes Processing Business Unit for Waste Pickers is feasible to run, with the profile of business aspects as follows:

The market opportunity is still widely open, as demand from waste collectors is unlimited and supply from waste pickers is limited.

Technically, plastic chopping units are designed mobile on motorcycles, so waste pickers can directly execute the production process in the field. Then, the result is directly stored to the waste collectors. This is also supported by waste picker's ability to repair minor 
damage in the chopper machine. The capability of waste pickers' production process still needs to be improved, with the training model or apprenticeship to waste pickers who already have the understanding and ability in the production process. The production process needs to be separated based on the thickness of the plastic because they have different prices.

Financially, this business can be categorized well, because it provides $47.96 \%$ profit from the money invested, or $46.52 \%$ of total sales value.

The organization of this business can be in the form of individual organizations and individual alliances. Although their education is high school graduates at the highest, managerial traits will always be found in an organization based on family relationship and friendship.

Legally, waste pickers have become good citizens by having an ID card and a permanent residence.

From the socio-economic aspect, this business will increase the waste pickers' income, improve the status of the waste pickers, and reduce social problems.

\section{REFERENCES}

1. Siregar, Padang Rihim, 2013, Profil Sektor Informal (Studi Pedagang Kaki Lima di Jalan Hang Tuah Kota Tanjungpinang), riset.umrah.ac.id, hal $249-258$.

2. Hermawani, May, 2013, Strategi Bertahan Pedagang Kaki Lima Di Sekitar Kampus Universitas Sumatera Utara, Undergraduate Thesis, repository.usu.ac.id.

3. Kristiyono, Fitra; Bakar, Abu; \& Yuniar, 2014, Analisis Kelayakan Pendirian Pabrik Pencacah Plastik Acrylonitrile Butadiene Stryrene (ABS), Reka Integra ISSN: 2338-5081 - Jurusan Teknik Industri Itenas - No.03 - Vol.01 - Januari 2014.

4. Margaretha,Farah.2011.Manajemen Keuangan.Erlangga.Jakarta

5. Prabowo, Hartiwi, 2012, Kelayakan Investasi Perluasan Pabrik Penggilingan Plastik Pd Xyz, BINUS BUSINESS REVIEW Vol. 3 No. 2 November 2012: 803-818.

6. Anggraeni, Mutiara; Desrianty, Arie; \& Yuniar, 2013, Rancangan Meja Dapur Multifungsi Menggunakan Quality Function Deployment (QFD), Reka Integra ISSN: 2338-5081 Jurusan Teknik Industri Itenas - No.02 - Vol.01 - Oktober 2013.

7. Suarmawan, Kadek, Agus, 2015, Analisis Faktor-Faktor Yang Mempengaruhi Keberhasilan Usaha Mikro Dan Kecil (Studi Pada Usaha Kerajinan Ingka Di Desa Bulian, Kec. Kubutambahan), Jurnal Jurusan Pendidikan Ekonomi (JJPE) - Volume: 5 Nomor:1 Tahun: 2015, Hal.: 1 - 10.

8. Adriantantri, Emmalia; 2008, Aplikasi Metode Quality Function Deployment (Qfd) dalam Usaha Memenuhi Kepuasan Pelanggan Terhadap Produk Aqua Gelas 240 Ml Pada Pt. Tirta Investama Pandaan, Prosiding Seminar Nasional Teknoin 2008 Bidang Teknik Industri.

9. Rahman; Abdul \& Supomo, Heri, 2012, Analisa Kepuasan Pelanggan pada Pekerjaan Reparasi Kapal dengan Metode Quality Function Deployment (QFD), JURNAL TEKNIK ITS Vol. 1, No. 1(Sept. 2012) ISSN: 2301-9271.

10. Siagian, Sondang P., (1996), Manajemen Sumber Daya Manusia, Bumi Aksara, Jakarta.

11. Sucipto, Edi. Oktaviani, Rina. \& Rizal. 2015. The effects of partnership and entrepreneurship toward business performance of oyster mushroom (pleurotusostreatus). Indonesian Journal of Business and Entrepreneurship, Vol. 1 No.1, January 2015, Page $32-41$.

(C) 2017 by the authors. Licensee RJOAS, Orel, Russia. This article is an open access article distributed under the terms and conditions of the Creative Commons Attribution (CC BY) license: http://creativecommons.org/licenses/by/4.0/ 